See discussions, stats, and author profiles for this publication at: https://www.researchgate.net/publication/270844683

\title{
Kant's Ethics of Grace: Perspectival Solutions to the Moral Difficulties with Divine Assistance
}

Article in The Journal of Religion · October 2010

DOI: 10.1086/654821

CITATIONS

10

1 author:

Stephen Palmquist

Hong Kong Baptist University

233 PUBLICATIONS 270 CITATIONS

SEE PROFILE

Some of the authors of this publication are also working on these related projects:

Project Talks about Philosophy View project

Project Translated publications View project
READS

92 


\title{
Kant's Ethics of Grace: Perspectival Solutions to the Moral Difficulties with Divine Assistance
}

\author{
Stephen Palmquist / Hong Kong Baptist University
}

\section{DOES KANT HAVE AN ETHICS OF GRACE?}

Throughout most of the history of Kant interpretation, the Sage of Königsberg has been portrayed either as a philosopher without any serious interest in religion ${ }^{1}$ or as one who sought to bolster an essentially secular moral philosophy by reducing religion to nothing but ethical conduct. ${ }^{2}$ When such interpreters turn to Kant's Religion within the Bounds of Bare Reason (1793), ${ }^{3}$ they typically ignore or explain away his references to divine assistance (e.g., 44-45) and his arguments that our practical need to believe in God justifies a believer's hope that a morally

\footnotetext{
${ }^{1}$ For a recent example of this common tendency, see George di Giovanni, Freedom and Religion in Kant and His Immediate Successors: The Vocation of Humankind, 1774-1800 (Cambridge: Cambridge University Press, 2005), 203-4.

${ }^{2}$ For a recent defense of Kantian ethics as explicitly "secular," see Jeanine Grenberg, Kant and the Ethics of Humility: A Story of Dependence, Corruption, and Virtue (New York: Cambridge University Press, 2005). Patrick Frierson effectively rebuts this portrayal of Kant in "Corruption, Non-ideal Theory, and Grace: A Response to Kant and the Ethics of Humility," Philosophy and Phenomenological Research 75, no. 3 (November 2007): 624-31, but opines in conclusion that Kant's own satisfaction with his appeal to grace "is not clear" (631). For a detailed history and thorough discussion of the reductionist interpretation of Kant's philosophy of religion, together with an explanation of why it is mistaken, see Stephen R. Palmquist, Kant's Critical Religion: Volume Two of Kant's System of Perspectives (Aldershot: Ashgate, 2000), chap. 6, revised and reprinted from "Does Kant Reduce Religion to Morality?” Kant-Studien 83, no. 2 (1992): $129-48$.

${ }^{3}$ Quotations from Kant's book Religion within the Bounds of Bare Reason (hereafter Religion) are from Werner S. Pluhar's translation (Indianapolis: Hackett, 2009). References cite the original German pagination provided in the translation's margins. This edition's literal translation of Kant's word Stück as "Piece" to label the four main divisions of Religion is superior to alternatives such as "book" or "part," for it highlights Kant's likely reason for choosing this unusual word: the book's four essays were originally to be published as separate journal articles, or "Pieces." Kant uses Stück to refer explicitly to a journal publication in Religion, 23n.
}

(C) 2010 by The University of Chicago. All rights reserved.

0022-4189/2010/9004-0002\$10.00 


\section{Kant's Ethics of Grace}

attuned divine being exists. ${ }^{4}$ This has given rise to a widespread tendency to assume, even among those who think Kant wanted to take empirical religions seriously, that his philosophy leaves no room for grace, especially in its Christian form as an expression of God's forgiveness of sin through vicarious atonement. Any semblance of grace, according to this common view, is rendered ineffectual by Kant's allegedly Pelagian emphasis on salvation by works. ${ }^{5}$

Some scholars in the past few decades have challenged this historically prevalent tendency in various ways. An initial, qualified challenge came in two articles by Philip Quinn. The first examines the relevant passages of Religion, portraying Kant's theory of atonement as focusing, like Anselm's, on the need to satisfy divine justice. ${ }^{6}$ While praising Kant for avoiding some pitfalls that plague Anselm's approach, Quinn also raises two "serious objections" against Kant, concluding that Kant leaves us in a muddle over how vicarious atonement actually works. ${ }^{7}$ In a sequel, Quinn recounts his understanding of Kantian grace, expanding his objections by noting certain inconsistencies between Kant's theory of "saving faith" and Christian understandings of vicarious atonement. ${ }^{8}$ As I shall argue in Section IV, interpreting Kant's position as an ethics of grace effectively neutralizes Quinn's allegation that Kant adopts a position antithetical to orthodox Christian faith.

A more robust defense of Kantian grace appeared in an article by Jacqueline Mariña, ${ }^{9}$ who offers "an analysis of the deep structure of

\footnotetext{
${ }^{4}$ For a detailed analysis of one such "religious argument" for God's existence, an argument often overlooked even by readers sympathetic with Kant's religious tendencies, see Stephen Palmquist, "Kant's Religious Argument for the Existence of God-the Ultimate Dependence of Human Destiny on Divine Assistance," Faith and Philosophy 26 (January 2009): 3-22. For an exhaustive treatment of the role hope plays in Religion, see Sidney Axinn, The Logic of Hope: Extensions of Kant's View of Religion (Atlanta: Editions Rodopi, 1994).

${ }^{5}$ One of many typical examples is Garrett Green, "Kant's Christian Apologetic," in Papers of the Nineteenth Century Theology Working Group, vol. 19, ed. Andrew Burgess, Joseph Pickle, and Hans Schwarz (Colorado Springs: Colorado College, 1993), 7. The most influential text arguing that Kant cannot consistently defend an orthodox concept of grace is John R. Silber, "The Ethical Significance of Kant's Religion," in Religion within the Limits of Reason Alone, trans. T. M. Greene and H. H. Hudson (New York: Harper \& Row, 1960), cxxxi.

${ }^{6}$ Philip L. Quinn, "Christian Atonement and Kantian Justification," Faith and Philosophy 3, no. 4 (October 1986): 440-62.

${ }^{7}$ Ibid., 441.

${ }^{8}$ Philip L. Quinn, "Saving Faith from Kant's Remarkable Antinomy," Faith and Philosophy 7, no. 4 (October 1990): 418-33.

${ }^{9}$ Jacqueline Mariña, "Kant on Grace: A Reply to His Critics," Religious Studies 33, no. 4 (1997): 379-400. Among the many other recent scholars who have contributed to this affirmative, grace-friendly way of interpreting Kantian theology and philosophy of religion are John E. Hare (The Moral Gap: Kantian Ethics, Human Limits, and God's Assistance [Oxford: Clarendon, 1996]) and Stephen R. Palmquist (Kant's Critical Religion). See also the essays by fourteen interpreters who adopt various types of affirmative approach, collected in Chris L.
} 


\section{The Journal of Religion}

Kant's views on divine justice and grace" that shows Kant's position, far from being Pelagian, to be consistent with "an authentically Christian understanding." ${ }^{10}$ Quoting from a wide variety of Kant's texts, Mariña demonstrates that for Kant "divine justice is punitive and not remunerative": because human beings are never entirely good and because God wills the happiness of all, any happiness we enjoy is a sign of "unmerited grace." 11 The good life conduct Kant emphasizes in Religion does not earn a person the right to divine grace but only makes one receptive to a gift God must freely give (if it is to be available at all). Carefully distinguishing between grace in general and two, more specific types of Kantian grace, Mariña defends Kant's argument against the specific objections raised by Quinn and by several other interpreters less sympathetic to Kant's approach.

Yet old habits die hard, for, despite the persuasiveness of Mariña's defense of Kantian grace against the charges of unorthodoxy and/or incoherence, some interpreters have continued to portray Kant's theory as an empty shell with little or no relevance to the concerns of actual religious believers. What is missing from previous interpretations such as those of Quinn and Mariña, I shall argue, is a clear awareness that one of Kant's central aims is to assess and resolve the ethical difficulties that arise for any theology of grace, not to develop his own theoretical account of how grace might occur.

The tendency to misread Kant as proposing a theology of grace, and to find him wanting as a result, is nowhere better illustrated than in Peter Byrne's recent book Kant on God. While granting the affirmative interpreters' claim that Kant sometimes clearly tries to make room for divine grace, Byrne also echoes the conventional claim that Kant never unequivocally defends this important feature of religious belief. He distinguishes between three types of grace-distributive, transforming, and justifying - that operate in Kant's writings. ${ }^{12}$ In the Dialectic of the second Critique Kant portrays God as distributing happiness (presumably, to justified believers) according to each person's inner disposition,

Firestone and Stephen R. Palmquist, eds., Kant and the New Philosophy of Religion (Bloomington: Indiana University Press, 2006). Most notable among them is Philip Rossi's essay, "Reading Kant through Theological Spectacles" (chap. 5), where Mariña's interpretation is compared positively to that of various Catholic theologians.

${ }^{10}$ Mariña, "Kant on Grace," 380.

${ }^{11}$ Ibid., 382.

${ }^{12}$ Peter Byrne, Kant on God (Aldershot: Ashgate, 2007), 140. Byrne's lengthy discussion of Kant's theory of divine grace appears on 139-51. By contrast, Robert Merrihew Adams ("Introduction" to Immanuel Kant, Religion within the Boundaries of Mere Reason, trans. George di Giovanni [Cambridge: Cambridge University Press, 1998], xxi-xxiii) distinguishes between prevenient, sanctifying, and justifying grace, claiming that Kant rejects the first, accepts the second, and gives a "cautious embrace" to the third. 


\section{Kant's Ethics of Grace}

not according to outward conduct. Byrne devotes most of his attention to examining this type of grace, with its close association to Kant's moral argument for God's existence-a central focus of Byrne's book.

Of the three types, Byrne thinks only distributive grace does "any real work" for Kant, yet this type relates mainly to technical issues arising out of the second Critique. ${ }^{13}$ Byrne acknowledges that Kant's appeal to the other two types, mainly in Religion, sets him apart from Enlightenment deists, but he regards this appeal as nonessential to the concerns of Kant's Critical System. ${ }^{14}$ In what follows I shall challenge this claim by examining how Kant solves three ethical difficulties that arise out of any belief in divine assistance, including his own account in Religion's Second Piece. Kant's treatment of these difficulties suggests that the grace discussed in Religion is distinct from (and does not necessarily entail) the distribution of happiness in proportion to virtue that plays such a crucial role in the second Critique. Examining the details of Byrne's distributive grace is therefore irrelevant to our present concerns. ${ }^{15}$ However, I shall return to his qualified dismissal of Kantian grace in Section IV when I assess the practical relevance that Kant's ethics of grace has for ordinary religious believers.

Because appealing to grace presupposes belief in sin, and sin is often treated as a philosophically objectionable belief, some readers expect Kant to show no serious interest in grace. Yet in the First Piece Kant

\footnotetext{
${ }^{13}$ Byrne, Kant on God, 138-51. Byrne uses this phrase repeatedly throughout his section on grace. I shall discuss the "work" done by Kant's alleged appeal to distributive grace in a subsequent footnote.

${ }^{14}$ Ibid., 169-70. Earlier, Byrne admits, apparently with the recent affirmative interpreters in mind, that for Kant "there might be a role for transforming grace in relation to the problem of radical evil"; but he thinks Kant's solution to this problem "is not talking about transforming grace at all" (148). Byrne's dismissal of the relevance of Kant's appeal to transforming and justifying grace results from his focus on Kant's moral argument; yet we must cast our net wider in the Critical System to see the relevance of these other types of grace.

${ }^{15}$ As Byrne admits (Kant on God, 141), Kant himself does not actually use the term "grace" in the second Critique to refer to the distribution of happiness to moral agents in proportion to the extent of their virtue. It is therefore debatable whether Kant would regard Byrne's "distributive grace" as an example of grace at all-though Byrne provides some fascinating arguments for reading Kant in this way (see 141, 148-49). If, for Kant, such distribution has more to do with satisfying divine justice than with the dispensation of (unmerited) divine grace, this would explain why he never calls it "grace." This possibility, together with the fact that nearly all the evidence Byrne amasses for seeing a doctrine of distributive grace operative in Religion comes from the First Piece and is part of Kant's explanation of the religious implications of radical evil, justifies my decision to ignore this aspect of Byrne's treatment of Kantian grace. In saying it is irrelevant to our present concerns, I am not staking any claim (positive or negative) regarding the merits of Byrne's discussion of distributive grace. Rather, I am merely pointing out that the present article is not about radical evil, but about how to resolve the ethical difficulties that arise for anyone who believes in divine grace. Kant's discussion of what Byrne calls distributive grace in the second Critique makes no mention of such difficulties.
} 


\section{The Journal of Religion}

defends a position he explicitly describes as expressing essentially the same meaning as the Christian doctrine of original sin. ${ }^{16}$ The crucial difference, Kant claims, is that the latter typically refers to the origin of evil in time (i.e., identifying who the first sinner was), whereas his theory of the "evil propensity" that infects human nature at its root is about the origin of evil in reason (Religion, 39-44). He claims our decision-making capacity-our rational power to make free choices-inevitably tends to be grounded in a preference for choosing evil, starting from our first choice. ${ }^{17}$ This stance, properly understood, requires Kant to appeal to grace in the Second Piece; as he predicts near the end of the First Piece (44-47), divine assistance may be necessary to release human beings from the self-deception caused by the radical evil that inevitably infects our reason. Why, then, does Kant step lightly around any direct appeal to grace when constructing his arguments in the Second Piece?

Kant's noncommittal treatment of grace stems directly from his fundamental claim, upheld throughout the three Critiques, that practical reason has priority over theoretical reason. ${ }^{18}$ The ethical implications of being religious (i.e., the practical outcome of adopting a given set of religious beliefs and practices) therefore matter to Kant far more than the abstract, metaphysical status of any theological doctrine. Consistent with this principle, we find throughout Religion, especially in the Second Piece (e.g., 62), that Kant repeatedly warns his readers of the ethical dangers that may arise for those who conceive of religion as requiring elements that go beyond the duty to follow a good way of life. Whatever else authentic religion may be, according to Kant, it must not become an excuse for moral laziness or immoral behavior (by either individuals or groups of alleged "believers"). In particular, he warns (66-78) that believers who ground their hope of salvation en-

\footnotetext{
${ }^{16}$ In Religion, Kant says: "The way of conceiving that Scripture employs to depict the origin of evil as a beginning of evil in the human genus agrees quite well with the above [i.e., with Kant's theory of the rational origin of evil]; for Scripture presents this origin in a story where that which by the nature of the case (without taking the time condition into account) must be thought as [being] first appears as first in time" (41).

${ }^{17}$ This evil propensity has the same (transcendental) status in relation to the possibility of religion as space and time have in relation to empirical knowledge. Because human nature has a predisposition to good, we must presuppose the presence of an evil propensity in all human beings to explain how even one person could choose evil. See Stephen R. Palmquist, "Kant's Quasi-Transcendental Argument for a Necessary and Universal Evil Propensity in Human Nature," Southern Journal of Philosophy 46, no. 2 (Summer 2008): 261-97, for a detailed analysis of the structure of Kant's argument along these lines.

${ }^{18}$ The key texts on the primacy of practical reason are Critique of Pure Reason, 825-32 ("B" edition), Critique of Practical Reason, 119-21, and Critique of Judgment, 171-73 (pagination is from the Berlin Academy edition).
} 


\section{Kant's Ethics of Grace}

tirely on the claim that God will change (or has supernaturally changed) them from being morally corrupt to being morally "good" are likely to fall victim to three religious illusions, whose basic features we shall review in Section II.

One of Kant's chief concerns in the Second Piece, entitled "On the Struggle of the Good [Principle] with the Evil Principle for Dominion over the Human Being" (Religion, 57), is to warn religious readers of the dangers of such self-deceptions. A person's evil propensity does not go away simply because he or she affirms a religious creed (e.g., 93-94); or, in response to one who believes God's grace does take away a person's evil propensity, Kant points out (67-71) that we can never know for certain that such a wholesale transformation has actually taken place in any given individual's case.$^{19}$ For ethical reasons alone, Kant thinks religious people ought to be cautious in affirming any specific theoretical doctrines about divine assistance.

Those who succumb to such religious illusions are likely to follow what Kant describes in the Third and Fourth Pieces as false religion. Yet his cautious treatment of how one ought to believe in divine assistance does not mean he positively rejects grace. A careful reading of the Second Piece reveals that Kant is aiming to reform the believer's understanding of grace rather than destroy it. Kant's goal is to reinterpret the Christian doctrine of grace in a way that renders it both philosophically coherent and ethically empowering, just as he claimed to do for the doctrine of original sin in the First Piece..$^{20}$ The goal of the First and Second Pieces, taken together, is to establish that, without belief in an ethically empowering conception of divine grace, ethical goodness becomes an impossible task. Kant's arguments in the main passage where he addresses the three difficulties that tend to arouse illusory forms of religious belief (Religion, 66-78) are often dismissed by interpreters as (at best) poorly argued or (at worst) nonsensical. ${ }^{21}$

\footnotetext{
${ }^{19}$ Mariña ("Kant on Grace") deals with this thorny issue in dialogue with Quinn (see, e.g., 386-87), concluding that the issue is ultimately irrelevant: Kant's position is that if one conceives of grace as a unilateral divine act that entirely does away with the evil propensity, then "we cannot really $d o$ anything with such an understanding of grace" (387).

${ }^{20}$ See n. 16 above.

${ }^{21}$ For example, in his writings on Kant's philosophy of religion, Gordon Michalson's standard approach is to portray Kant as responding to differing influences (such as Christian theology and Newtonian physics) that are ultimately incompatible. Armed with this assumption, Michalson finds irreconcilable "wobbles" throughout Kant's text. For Michalson's treatment of the three difficulties (though readers unfamiliar with Kant's text might have little awareness from Michalson's presentation that Kant presents them as three distinct problems), see Fallen Freedom: Kant on Radical Evil and Moral Regeneration (Cambridge: Cambridge University Press, 1990), 110-24.
} 


\section{The Journal of Religion}

Such assessments arise when interpreters neglect the thoroughly perspectival character of Kant's philosophy, remaining closed to what Mariña calls the "deep structure" of his arguments. ${ }^{22}$

Kant's main purpose in section one of Religion's Second Piece is to explain the conditions we must fulfill in order to overcome the effect our evil propensity has on our moral character. Adopting the transcendental perspective, the First Piece portrayed radical evil as the boundary condition that initially gives rise to the need for religion. ${ }^{23}$ The Second Piece then adopts the logical perspective to explain how the internal presence of a divine Word ( $\lambda$ ó $\gamma o \varsigma)$, or "archetype," can empower religious believers to return the good principle to its rightful place of sovereignty over the will. Subsection A (Religion, 60-62) argues that bare reason recognizes in itself an unfulfilled need that can be met only by this $\lambda$ ó $\gamma$ os taking on human form, as a perfect example of moral goodness. Subsection B (62-66) argues that, because human beings are aware of this need and can identify such an example, this archetype must be an internal reality that can empower a person to effect a conversion from evil heartedness to good. Although human beings may need a real historical example of an ideal person in order to be aware of this inner power, authentic religion calls each person to become such an example of goodness. Reconciling this need with the three illusions that tend to accompany any belief in grace is Kant's central task in subsection C (67-78), where he defends what I am here calling his "ethics of grace."

\section{THE TENDENCY OF GRACE TO ENCOURAGE MORAL LAZINESS}

Although only three of the thirty-nine occurrences of "grace" (Gnade or Gnaden) and its equivalents in Religion appear in subsection C, this is where we find Kant's most thorough discussion of the ethical dangers confronting a person who believes in divine grace. Kant's arguments in this passage are typically not regarded as successfully defending a doctrine of grace because he never focuses on, or clearly explains from God's perspective, how grace is actually implemented. This apparent omission ceases to be disconcerting, once we recognize that he is here not constructing a theology but an ethics of grace: a philosophical defense of how a person can choose to believe in divine assistance without

\footnotetext{
${ }^{22}$ For a thoroughgoing examination of this aspect of Kant's philosophy, see Stephen R. Palmquist, Kant's System of Perspectives: An Architectonic Interpretation of the Critical Philosophy (Lanham, MD: University Press of America, 1993).

${ }^{23}$ For more detail on how Kant's four main perspectives can be correlated to the four main divisions of Religion, see Palmquist, Kant's Critical Religion, chap. 7.
} 


\section{Kant's Ethics of Grace}

thereby becoming morally lazy and of why a person might choose such practical faith rather than trust solely in the merits of good life conduct. $^{24}$

Kant's ethics of grace, his explanation of the proper relationship between grace and virtue, reaches a climax near the end of section one, where he reveals that the whole topic of subsection $\mathrm{C}$ concerns "that surplus beyond the merit of works" (75) that "is a merit that is imputed to us by grace." He then summarizes his foregoing argument (75-76): ${ }^{25}$

For that what, in our case . . is always only in [a state of] mere becoming (namely, to be a human being pleasing to God) should be imputed to us as if we were already in full possession of it here-to this, after all, we surely have (according to empirical self-cognition) no legal claim* insofar as we are acquainted with ourselves in that way (gauge our disposition not directly but only according to our deeds), so that the prosecutor within us would still be more likely to propose a judgment of condemnation. It is therefore always only a verdict of grace, although fully in conformity with eternal justice (as based on a satisfaction thereof which for us resides only in the idea of the improved disposition but with which God alone is acquainted), when we for the sake of that good in our faith are unburdened of all responsibility.

Kant's footnote to the quoted paragraph defines grace as "the decree of a superior to bestow a good for which the subordinate has nothing but the (moral) receptivity" (75n). Here, and only here in subsection C, does Kant explicitly define grace. But this need not be treated as an oversight, if his purpose in these pages is not to theologize, but to explain how one can believe in such a decree without becoming ethically lazy.

As I noted in Section I, Kant argues in subsection A that an "archetype" within every person provides an idea or image of what living a life of constant dependence on the "good principle" would entail and that faith in this archetype can empower us to overcome the debilitating influence of the radical evil infecting our nature as rational beings who are free, yet also products of physical nature. Subsection B assesses the proper role of examples in such "practical faith" (Religion, 62): that

\footnotetext{
${ }^{24}$ Di Giovanni claims Kant "was remarkably indifferent to religion" and an "atheist, for all practical purposes" (Freedom and Religion in Kant, 203). That Kant tended to ignore traditional religious beliefs and practices "in his private life" (204) di Giovanni interprets as stemming from "righteous self-assurance," rather than being a legitimate expression of his revolutionary view of what true religion is all about, as I shall argue in the remainder of the article. For my refutation of the claim that "Kant's intention" was "to contain the sacred within the boundaries of reason" (204), see my review of di Giovanni's book in Kant-Studien 101, no. 1 (2010): 137-41.

${ }^{25}$ Wherever Pluhar has "attitude" for Kant's technical term Gesinnung, I use the more conventional "disposition."
} 


\section{The Journal of Religion}

we can identify perfection in another person, such as Jesus, means we must first possess the idea of a perfect person within ourselves; so each person must strive to make oneself that perfect example. In this context, subsection C examines three "Difficulties Opposing the Reality of This Idea" (66) of an inner archetype of perfection that we can call upon to empower our ethical decision making. Solving these difficulties forms the core of Kant's account of why rational persons who wish to be good cannot depend merely on their own conduct but are better off appealing to divine grace. However, if calling upon this all-important idea itself becomes a form of self-deception, only weakening a person's moral resolve instead of strengthening it, then practical reason would be forced to discard the archetype, and all religion based on such an idea would be a dead end-at least as far as its goal of empowering ethical behavior is concerned.

What, then, are the three ethical difficulties Kant is so worried about? They are well known, as Kant's account of each is frequently summarized in the literature $;{ }^{26}$ because our focus here is on how Kant solves these difficulties, a brief initial paraphrase of each illusion, and the difficulty it creates, will suffice. First, believers in grace tell themselves they are "saved," yet they often continue to behave in a way that a good God would regard as morally deficient. How could God overlook the evil deeds a believer continues to commit, after conversion? Divine assistance to those who are saved by grace seems to require God to turn a blind eye to real evil, thus inadvertently encouraging religious people to continue doing evil with a clear conscience, in the belief that God sees them as "good" regardless of how bad their conduct may be. If this is what grace entails, then the idea of an archetype of perfection obviously lacks "reality" (Religion, 66) inasmuch as it thwarts the practical goal it claims to reach. Kant's portrayal of grace attempts to solve this problem.

\footnotetext{
${ }^{26}$ Accurately paraphrasing these difficulties requires an awareness of how they correspond to the traditional theological doctrines of justification, eternal assurance, and sanctification. Two early summaries worth consulting are Allen W. Wood's Kant's Moral Religion (Ithaca, NY: Cornell University Press, 1970), 233-35; and Ronald M. Green's Religious Reason: The Rational and Moral Basis of Religious Belief (New York: Oxford University Press, 1978), 86-88. See also Patrick Frierson, Freedom and Anthropology in Kant's Moral Philosophy (Cambridge: Cambridge University Press, 2003), 114-22. Hare's summary correlates Kant's three difficulties to the persons of the Trinity and to the distinction between past, present, and future (Moral Gap, 53-56); emphasizing these theoretical issues instead of Kant's ethics of grace, Hare ends up joining those who regard Kant's attempt to solve the difficulties as a "failure" (60). Adams includes a helpful discussion of Kantian justification and grace ("Introduction," $\mathrm{xv}-\mathrm{xxv}$ ). Although he never mentions the three difficulties, Adams does acknowledge their core concern: Kant thinks moral faith needs to appeal to grace, yet "fears the concept of grace for the potential he sees in it for a corrupt relaxation of the stern demands of morality" (xxi).
} 


\section{Kant's Ethics of Grace}

Second, an alleged certainty of having been declared blameless before God, now and forever, may lead to moral laziness even among those who really have become good in God's eyes, causing them to lapse into a way of life that a good God could not possibly endorse. Can religious believers know for certain that God has assisted them in an eternally efficacious way? Many people claim such absolute certainty; but if this is possible, to the extent that even God could not "unsave" such persons, then what would prevent grace-filled believers from falling back into the evil ways that necessitated their conversion in the first place? Any theory of divine assistance that leads to such an outcome, including Kant's own theory of the archetype, would encourage belief in something that lacks reality, at least for the practical (ethical) purpose of becoming a better person.

Third and perhaps most dangerously deceptive of all, believers might think they are no longer responsible for their preconversion life, because God has forgiven them for their past evil. This understanding of divine grace lies at the core of Christian theology, so Kant's assessment is historically accurate when he says it offers the "greatest" challenge (Religion, 71) to anyone attempting to construct an ethics of grace. How can a good God forgive evil deeds done prior to a person's conversion without wholly ignoring the requirements of justice implied by the moral law? Christianity teaches, and Kant sometimes affirms (e.g., 73-77), that the only way to conceive of God as forgiving believers for preconversion evil is for someone else to be punished for that evil. Yet Kant assumes (without argument) that an ethical interpretation of religion requires each person to be responsible for his or her own choices. Belief in vicarious atonement would therefore seem to destroy the practical reality of the idea that religious believers themselves become perfect through their faith in the inner archetype. If it is not me, but Jesus, whom God sees as the "perfect individual," then ethically, religious belief is a sham: I can remain as mired as ever in the radical evil I hoped to escape by affirming a belief in salvation by grace.

Here, as in each of the three difficulties, the explanation of grace commonly accepted by Christians, often promoted by their pastors, and sometimes even defended by theologians, fails to protect believers from experiencing potentially dire consequences for their ethical integrity. Such a belief may cause the religious person to be less able to live a good life, rather than providing a newfound power to do so. Belief in divine grace would then defeat the ethical purpose of being religious. What readers of subsection $\mathrm{C}$ must constantly keep in mind, in order to understand how and why Kant solves these difficulties, is that any theoretical claims he makes are presented solely to show how 
The Journal of Religion

philosophers well tuned to the workings of practical reason can protect believers from deceiving themselves: people affirming a theological belief in divine assistance (whatever the details may be) must supplement it with an ethics of grace.

III. KANT'S ANTIDOTE TO MORAL LAZINESS: SOLVING THE THREE ETHICAL DIFFICULTIES

While the nature of the three difficulties Kant finds with any theology of grace is well known and tends to be understood fairly accurately by his interpreters, the depth and power of his solutions have never been fully appreciated. In this section I shall fill that gap by explaining how Kant's solution to each difficulty relies on a basic hermeneutic strategy: whereas those who interpret grace in an overly simplistic, nonperspectival way end up compromising their ethical integrity, those who adopt a perspectival interpretation are empowered to live a more authentic, ethically motivated life. I shall focus mainly on Kant's solution to the third difficulty, for although it is the most important, it is also the most obscure of his solutions, so it has been the easiest to dismiss without serious consideration.

Kant's response to all three difficulties is grounded in a perspectival understanding of what religious belief entails: to be both genuinely religious and fully rational, a person must believe in a God who perceives the spatiotemporal details of human beings' lives as a completed whole, from a "noumenal" perspective unavailable to human beings. By contrast, we human beings are limited to the "phenomenal" perspective, whereby we perceive only specific deeds and choices in isolation from the totality that makes up a person's moral life. By remembering that they cannot have knowledge of the noumenal and that human judgments regarding a person's ethical condition must be based on only phenomenal evidence, religious believers can effectively protect themselves against ethical illusion. The ethical obstacles that threaten to prevent a morally sensitive, rational person from believing in divine grace can likewise be cleared away, provided we interpret grace within this framework-a framework wholly consistent with (indeed, determined by) Kant's Critical philosophy.

This perspectival framework, with its core distinction between the phenomenal and the noumenal, lies at the heart not only of Kant's epistemology, moral philosophy, and aesthetics but also of his account of the nature and purpose of religion. Of course, such references to "noumenal reality" bear the brunt of much criticism of Kant's entire philosophy, including his theory of religion, with its apparent depen- 


\section{Kant's Ethics of Grace}

dence on the mysterious notion of a "timeless choice." The phenomenanoumena distinction is intimately bound up with a perspectival distinction Kant makes in the first Critique, between "empirical" reality, the "transcendental" conditions that make that reality possible, and the "transcendent" reality (if any) that lies out beyond the limits of our possible knowledge. As I have argued elsewhere, many of these longstanding problems can be cleared up by viewing these not as different realities, but as different perspectives on (or ways of viewing) one and the same reality, whose nature in and of itself is best called "human experience." With this perspectival framework in mind, I shall clarify in Section IV what Kant means by his otherwise obscure concept of noumenal choice. But first, let us examine how he applies this perspectival framework to solve the ethical difficulties confronting anyone who believes in grace.

Kant solves the first difficulty by positing a divine perspective, whereby God views a religious person's entire life as a single, coherent whole. By viewing a person's life from this noumenal perspective, God is able to take the progress that person makes over time as equivalent to completing the goal of being perfect, even though each person (as far as we know, from our limited, phenomenal perspective) dies before the process of moral growth reaches full fruition. This hypothetical way of thinking about God does not provide or require any theoretical knowledge of God's existence or nature, yet it empowers believers to persevere in their moral life: even though they still occasionally make choices contrary to the moral law, they can now understand how a good God can "justify" them without merely turning a blind eye to their postconversion evil. Kant's account fulfills the task of an ethics of grace by discouraging believers from becoming morally lazy as a result of their belief in divine justification. If the rational grounding of belief in justification is the empirical observation that a person's moral life is progressing, then this very belief will encourage the person to work more diligently to make a real difference in the phenomenal world, for that is the only basis we human beings can use, on Kant's account, to assess our own eternal destiny. That is, people who adopt Kant's perspectival solution to the first difficulty not only are rationally permitted to believe in the justifying power of divine grace, but by doing so in the proper way they are also empowered to live more ethically even though the doctrine they affirm remains theoretically problematic.

Kant solves the first ethical problem that has historically plagued those who affirm the doctrine of justification by grace by requiring believers to treat evidence of sanctification (i.e., the phenomenal pro- 
The Journal of Religion

cess of becoming a better person) as a necessary condition of believing one has been (noumenally) justified by God. This makes moral laziness incompatible with belief in grace. But how can a person know whether or not any real (phenomenal) progress has been made? Kant answers this question in his response to the second difficulty.

Kant observes that complete assurance of salvation is likely to be as detrimental to a believer's moral condition as a total lack of any basis for confidence would be. Rational persons who presume to know God has irreversibly saved them might as well choose to relax and live a self-centered, essentially evil life, since their eternal destiny is a "done deal." Divine assistance would then have an unethical result, and the morally sensitive rational person would have to regard grace as yet another example of our tendency to be duped by the radical evil that infects human reason at its root. Likewise, those who deny the possibility of possessing any evidence as to whether or not they are saved would be likely to stop trying to live a good life. Kant solves this difficulty by appealing once again to his perspectival framework, requiring believers to focus on their phenomenal choices rather than claiming to have knowledge of a noumenal reality that is beyond human grasp. Certainty on such matters is possible only from God's perspective, a perspective we human beings can never hope to adopt. Instead, religious believers must always assess the eternal status of their disposition by appealing to life conduct, for this phenomenal perspective on the status of moral character is the only means we have for obtaining evidence of whether or not we have been transformed by God's grace. That our assessments will always remain imperfect is not ethically problematic, for the goal of focusing on continual progress is not to obtain certainty of salvation, but to guard against moral laziness.

The interpretation of divine grace Kant defended in response to the first difficulty gives believers who remain morally diligent (i.e., those who think they observe progress toward the goal of perfection in their experience since conversion) a reason to hope that from God's point of view their salvation is secure. Such hope thereby empowers religious believers to work even harder, without tempting them (as do either of the extreme alternatives) to stop working on moral self-improvement. This solves the second difficulty by enabling a person to continue believing in the transforming efficacy of divine grace, without having an excuse to be morally lazy, as a claim to certainty would provide. By requiring those who believe in grace to regard it as noumenal, thus appealing only to the (uncertain) phenomenal evidence of moral improvement as a basis for religious hope, Kant remains well within the limits of knowledge set by the first Critique. 


\section{Kant's Ethics of Grace}

Kant's response to the third difficulty is less straightforward; if read theologically, it appears at first to be a concocted solution with no tangible effect on a believer's practical empowerment. Yet when taken as the third step in a systematic attempt to construct an ethics of grace, it turns out to be the most profound of the three solutions. Along with orthodox Christian theologians, Kant assumes that the ethical requirements of divine justice can be satisfied only if some punishment is dealt out to compensate for the evil done prior to a person's conversion (Religion, 72-74) and that conversion entails the believer becoming a "new person" from the moral standpoint, even though from the standpoint of one's physical nature, one remains the self-same individual. We would expect to account for the timing of God's punishment by locating it either before or after the conversion experience (73); but Kant rejects both options. Human experience fails to provide consistent evidence that God punishes evil-hearted people directly for their evil; often, those who choose to do evil seem happier than good people, for they intentionally pursue their own happiness before considering the demands of the moral law. ${ }^{27}$ Moreover, the price for preconversion evil cannot have been paid by suffering endured before conversion, because this would imply that an evil-hearted person (one who has not experienced conversion) is in no need of God's grace, having already paid the price for the evil done! Yet the punishment also cannot occur after conversion, because at this point, a genuinely converted person has a good disposition and is thereby not worthy of being judged evil. In the process of solving the first difficulty Kant has already explained how a just and righteous God could save such a person without needing to administer any postconversion punishment.

In typical Critical fashion, Kant solves this dilemma by appealing to a middle way hidden between the two extremes: if the punishment that atones for a person's preconversion evil can occur neither before nor after the person's conversion, it must "be thought as commensurate with this change and carried out in the state of the change of mentality itself" (Religion, 73). What could this mean? For if conversion involves a change of disposition, and if its noumenal nature means that only God has unobstructed access to the human disposition, then how could a "change" in this "timeless" aspect of our nature have an effect in the phenomenal world? Kant's argument appears to be as meaningless as the worst examples of scholastic hairsplitting; if we read this as an attempt to construct a theology of grace, he might as well be asking

\footnotetext{
${ }^{27}$ Kant defines "wickedness" as "revers[ing] the moral order in regard to the incentives of a free power of choice" (Religion, 30), where the proper order of incentives is respect for the moral law, followed by happiness.
} 


\section{The Journal of Religion}

us to decide how many angels can stand together on the head of a pin! Unfortunately, Kant offers precious little clue as to what he has in mind, so not surprisingly, interpreters tend to reject this and all his solutions as "ambiguous" and "unsatisfactory." 28

Interpreting Kant's third solution as the climax of his defense of an ethics of grace gives it considerably more practical force. We can then understand his argument as follows: the experience of conversion just is the deeply painful choice to submit one's ethical decision-making processes to a new foundational principle. The "old person" was someone for whom evil choices tended to cause intense pleasure, while no pain seemed more unbearable than being forced to do a good deed one would rather avoid. Guilt is a remote and rare feeling for such a person. For the "new person," by contrast, evil choices cause a pain of guilt more intense than anything the "old person" ever experienced. While all human persons tend to feel some of the "pain" Kant identifies as respect for the moral law-for even the most deeply spiritual persons have physical and sensuously conditioned inclinations-the primary mark of growth in one's moral life (or of sanctification in one's religious life) is that this pain gradually develops into a deep contentment when one has decided (noumenally) to base one's moral choices on the good principle..$^{29}$ Since the experience of conversion is not necessarily sudden, but may extend over a lengthy portion of a person's life, the existence of such "pain" can be taken as empirical evidence that one is still "in the state" of undergoing such a phenomenal change (i.e., of being sanctified).

An easily neglected aspect of Kant's solution to the third difficulty is that, even though he depicts the crucial pain and suffering under consideration as happening during the conversion experience, he also says the new, postconversion person suffers vicariously on behalf of the old, preconversion person. In deciding, once and for all, to aim at living a virtuous life, a person undergoing a conversion agrees to experience the aforementioned pain of ever-increasing guilt; ${ }^{30}$ for, the closer one comes to being holy (or sanctified), the more one becomes

\footnotetext{
${ }^{28}$ Michalson, Fallen Freedom, 111, 122, and passim. Wood, for example, claims the question Kant asks here "is not to the point" (Kant's Moral Religion, 235), though he then argues that important theological insights can be gleaned from Kant's discussion.

${ }^{29}$ In Critique of Practical Reason (trans. Werner S. Pluhar [Indianapolis: Hackett, 2002], 73) Kant writes: "the moral law as determining basis of the will . . . must bring about a feeling that can be called pain." He goes on to describe this pain as a need to eclipse the inclinations of self-love when we choose to give precedence to the principle of respect for persons that is inherent in the moral law.

${ }^{30}$ Apparently, this agreement is "timeless," so it does not necessarily enter consciously into the believer's mind during the process of conversion. I attempt to make sense of this claim, arguably the most problematic in all of Kant's philosophy of religion, in Section IV.
} 


\section{Kant's Ethics of Grace}

aware of the depths of one's failings. Kant's claim is that the painful awareness accompanying a conversion experience, that my moral disposition must be turned completely around in order for me to receive divine grace, constitutes the phenomenal "punishment" that enables God to forgive my preconversion evil. Focusing on this deeply painful experience, whereby a person realizes his or her past life has been so mired in evil that the only hope is to "die" (82) to "the old human being" (74) and commit oneself, with God's help, to carrying one's cross down the never-ending path of self-improvement (73-78), enables us to understand how God can forgive preconversion evil while avoiding the danger of allowing believers to be morally lazy. Kant is suggesting, therefore, that the empirical evidence that a person has been morally receptive to the atoning work of Jesus (or any other theological basis for divine grace) is that the person must seek to conduct his or her life in a manner that amounts to the imitation of Christ's sufferings-a theme he develops further in section two of the Second Piece. Unfortunately, examining the precise nature of this pain and the psychology of conversion it implies is beyond the scope of the present essay. Let it suffice to say that, in order to overcome the ethical difficulty created by a belief in justification, we must acknowledge the importance of the psychologically painful experience of sanctification as evidence that the required (noumenal) change has occurred. While this is consistent with the position many of the great Christian theologians have defended down through the centuries, ${ }^{31}$ it is lost in much of the popular theology that is the target of Kant's criticism in Religion.

IV. KANT'S AFFIRMATION OF GRACE AS A NOUMENAL IDEA WITH

RELIGIOUS POWER

Peter Byrne's recent discussion of Kant's hesitancy in affirming a qualified doctrine of grace for rational religion (see Sec. I) portrays Kant's God as devoid of any real power to influence the way religious believers conduct their lives. Against this claim, I have argued that Kant's position, at least in the key passage interpreted in Sections II-III, has an ethical emphasis that gives it far more practical power than Byrne acknowledges. What remains is to show how Kant's controversial appeal to the noumenal origin of grace serves to clear away the ethical obstacles that might otherwise obstruct a practical justification for believing in grace as a real power.

${ }^{31}$ A typical example is the Catholic theologian Louis de Molina (1535-1600). For other examples, see Rossi, "Reading Kant." 


\section{The Journal of Religion}

Although Byrne does not discuss Kant's account of the three difficulties in any detail, his three types of grace are related, at least loosely, to Kant's three solutions. Byrne's account of distributive grace in Religion focuses on the First Piece and thus makes no reference to anything Kant defends explicitly in the Second Piece; nevertheless, those familiar with the second Critique may detect a parallel between Kant's solution to the first difficulty (how God can forgive good-hearted people for their remaining imperfections) and the moral-religious situation whereby God distributes happiness to justified believers. ${ }^{32}$

Byrne describes "justifying grace" as God making a converted person perfect even though the person "is still left with guilt from the bad acts he performed while an imperfect being." ${ }^{33}$ As such, this type of grace obviously refers to the Christian doctrine of vicarious atonement and is precisely the source of Kant's third difficulty. Unfortunately, Byrne makes no effort to relate his account of Kantian justifying grace to Kant's solution to this difficulty. Yet, as I have argued in Section III, Kant's solution to the third difficulty relates as much to the traditional doctrine of sanctification as to justification, for the "difficulty" here is not how salvation (i.e., justification) itself is possible, but how religious believers compensate for past evil through their painful commitment to self-improvement-a task that corresponds closely to what theologians typically call "sanctification."

Byrne covers sanctification under the heading "transforming grace," describing it as "the alleged divine ability and willingness materially to assist in transforming the evil human being into the good human being." ${ }^{44}$ On Byrne's reading, Kant has no serious interest in either transforming grace or justifying grace, except insofar as these are in some sense "analogous" to distributive grace. ${ }^{35}$ By setting up his own three-

\footnotetext{
${ }^{32}$ Although it can be read into the text, Kant's account does not require such an implicit connection. Divine grace as Kant describes it when solving the first difficulty has no direct dependence on the distribution of happiness. Just as Kant never uses the term "grace" in the second Critique to describe the process whereby everyone ends up with happiness in direct proportion to their virtue, in Religion he never says the justified believer deserves to receive from God a gift of happiness in proportion to the level of virtue attained. Kant made a valiant effort (see Religion, 14) to keep the validity of his conclusions in Religion distinct from the validity of the conclusions of the three Critiques. My point in the text is only that a potential parallel exists here that Byrne overlooked.

${ }^{33}$ Byrne, Kant on God, 140.

${ }^{34}$ Ibid.

${ }^{35}$ Ibid., 141. Byrne here mentions Kant's definition of grace (Religion, 75n), quoted above in Sec. II. Later, Byrne devotes part of one paragraph (Kant on God, 150) to a brief discussion of several quotations from Kant's subsection C. But nowhere does Byrne acknowledge that Kant's attempt to solve these difficulties constitutes his most detailed discussion of how belief in grace can be morally empowering. In Byrne's case this oversight appears to have resulted from his overemphasis on the alleged role of the highest good in Religion: Kant mentions
} 


\section{Kant's Ethics of Grace}

fold distinction, reading it into Kant's text, then giving only passing attention to the very section of Religion where Kant offers his most powerful defense of the relevant theories, ${ }^{36}$ Byrne conflates aspects of grace that Kant himself distinguishes quite clearly. Kant addresses Byrne's transforming grace in solving both his first and second difficulties, where he clarifies that a belief in God's transforming grace is possible (i.e., it need not give rise to an ethically problematic position) as long as the believer does not count on such transformation as an excuse for moral laziness, but rather views the transformation as a motivating force that empowers a person to continue working on moral improvement. An appeal to transforming (i.e., noumenal) grace, according to Kant, is needed to compensate for what we ourselves, in our postconversion state, remain unable to complete during the process of phenomenal self-improvement.

A fair assessment of Kant's defense of the meaningfulness of divine grace in the face of the three difficulties requires a clear understanding of the noumenal language he uses in its defense, especially his several references to a mysterious, "timeless" choice. Let us therefore examine Kant's use of such language in hopes of making sense of it. Noumenal acts of timeless choice, Kant claims, must be presupposed to explain both how our disposition can start out evil and how a conversion to the good is possible. We can therefore take as paradigmatic what Kant says about the former noumenal choice. Whatever "act of freedom" (Religion, 21) must be inferred, in order to explain how we started out with an evil propensity, must have a status comparable to any followup "change of mentality" (Sinnesänderung; 66, 73-74, 83, 88) that succeeds in reversing that inner tendency.

Toward the end of the First Piece, Kant, when attempting to distinguish his theory of the rational origin of evil from the traditional theological interpretation of original sin as a temporal origin of evil, writes:

Every evil action must be regarded, when one seeks its rational origin, as if the human being had fallen into it directly from the state of innocence. For however his previous conduct may have been, and of whatever kind may be the natural causes influencing him, and likewise whether they are to be found within or outside him, his action is nonetheless free and not determined by any of these causes, and it therefore can and must always be judged as an original use of his power of choice. He should have refrained from the action, whatever the circumstances of time and the connections in which he may have been; for through no cause in the world can he cease to be a freely acting

the latter concept only a few times (e.g., Religion, 97) and never in a way that would make distribution of happiness in proportion to virtue a necessary feature of his argument.

${ }^{36}$ Byrne's passing attention to subsection $\mathrm{C}$ is discussed briefly in the previous footnote. 


\section{The Journal of Religion}

being. It is indeed rightly said that one imputes to the human being also the consequences arising from his former free but unlawful acts; but this means only that one has no need to venture into the subterfuge of establishing whether the consequences may be free or not, because, in the admittedly free action that was their cause, sufficient ground for imputation is already available. (Religion, 41)

Given that Kantian freedom is a noumenal reality, not conditioned by phenomenal causes and effects, the "free action" Kant refers to here is obviously an example of noumenal (or timeless) choice. He is not saying our empirical situation is wholly irrelevant, but only that, when assessing a person's moral character (based as it is on what is universal in human nature), our usual, phenomenal perspective on our actions cannot show us the disposition as such. The temporal effects of our free choice may be relevant to an earthly judge when determining the precise extent of our accountability for an evil (or good) act; but this is not what determines the bare (noumenal) fact that we are accountable.

The passage above reveals that the elusive timeless "action" whereby we choose the evil propensity is not some mysterious prebirth experience that takes place in an imaginary (mythical) realm beyond time and space. Rather, Kant's argument is that each and every moral choice can be viewed from two perspectives: viewed transcendentally, a moral action is grounded in a noumenal choice that makes us responsible for whatever we end up doing to implement that choice; viewed empirically, the same action takes place in time and space and may be influenced by all manner of exigencies. Insofar as such empirical causes are beyond our control, they may influence how accountable we are. ${ }^{37}$ Nevertheless, there are not two choices, nor two acts, but only one choice, one act that we can interpret from two perspectives. The same must be true of the free act whereby a person brings about a Sinnesänderung.

On this perspectival interpretation, "timeless" and "noumenal" refer not to some mysterious other world, but to a special way of viewing the

\footnotetext{
${ }^{37}$ In law courts, for example, a person who has been convicted of committing a crime is likely to receive a lighter sentence (or possibly none at all) if the judge is persuaded that causal factors diminished (or completely annulled) the person's ability to make a free choice. One who murders in a sudden fit of uncontrollable insanity is deemed less accountable than one who murders after making a cold, calculating decision. While the literature on Kant's theory of causation is massive, relatively little of it examines this most interesting question of how empirical causes can affect moral responsibility. See, e.g., Paul Guyer, Kant and the Claims of Knowledge (Cambridge: Cambridge University Press, 1987), 237-66. Michael Friedman ("Causal Laws and the Foundations of Natural Science," in The Cambridge Companion to Kant, ed. Paul Guyer [Cambridge: Cambridge University Press, 1992], 193 n. 7) lists fifteen influential publications on Kantian causality.
} 


\section{Kant's Ethics of Grace}

ordinary moral choices we make while living our phenomenal lives. Kant concludes the above-quoted paragraph by insisting (Religion, 41): "We therefore cannot inquire into the temporal origin of this deed, but must inquire merely into its rational origin, in order thereafter to determine and, if possible, explain the propensity, if there is one, i.e., the subjective universal basis for the admission of a transgression into our maxim." Any talk of a free choice to correct this propensity to evil in our nature must likewise be interpreted as an appeal to a change in our underlying moral character, our disposition. A good example of Kant's appeal to such a perspectival interpretation of grace comes in the footnote he appends to the last paragraph dealing with the third difficulty in subsection $\mathrm{C}$.

In a footnote clarifying his solution to the third difficulty, Kant emphasizes how our dual nature requires us to adopt two perspectives on punishment and justification:

Even the purest moral disposition still produces in the human being, as a being of the world, nothing more than a continual becoming of a subject who is pleasing to God in terms of the deed (which is found in the world of sense). In terms of quality this disposition (since it must be thought as suprasensibly based) ought to and can indeed be holy and conforming to the disposition of the human being's archetype; in terms of degree-as it reveals itself in actions-it always remains deficient and infinitely far removed from that archetype's disposition. In spite of this, because this disposition contains the basis for continual progress in compensating for this deficiency, it takes the place of the deed in its perfection. (Religion, 74n-75n)

Viewed from the noumenal perspective of its supersensible nature, the "quality" of our moral nature "can indeed be holy and conforming to the disposition of the human being's archetype." Yet, viewed from the phenomenal perspective of the "degree" of conformity apparent in one's day-to-day actions, a person's moral status is (at best) in a perpetual process of improvement, for it always falls short of the goal of being "pleasing to God"-both "in life on earth" and "perhaps also in all future times and in all worlds" (75). The perfected disposition atones for this "deficiency" in life conduct by standing in place of such "continual progress" in a person's actions, though only when viewed from God's perspective-something we human beings can never do in any given case.

Kant's long footnote concludes by observing, ironically, that goodhearted persons will experience divine punishment as both cause and effect of their good life conduct, as well as of their "contentment" with the paradoxes involved in living a moral life (Religion, 75n): 


\section{The Journal of Religion}

Of this [i.e., the moral agent's "willing reception of those ills and sufferings as so many occasions for testing and practicing his disposition toward the good"] even that punishment is the effect and simultaneously the cause, and hence is so also of that satisfaction and moral happiness which consists in the consciousness of his progress in the good (which is one with the act of the abandonment of evil). In the old disposition, by contrast, the very same ills would have to have not only counted as punishments but also been sensed as such, because even considered as mere ills they are still directly opposed to what the human being in such a disposition makes his single goal by way of physical happiness.

Because the noumenal "act of the abandonment of evil" is "one with" a person's "consciousness of his [phenomenal] progress in the good," one who recognizes this unity may regard this act as entailing a divine "punishment" that paradoxically produces "moral happiness" despite the earthly "ills" a good person must endure. By contrast, when those who remain mired in an evil disposition are deprived of fulfilled inclinations, they adopt only the phenomenal perspective, counting "the very same ills . . . as punishments," for this is how they have "been sensed" (i.e., how they appear to one's physical nature); the "single goal" for such persons is to obtain the "physical happiness" that is possible only by fulfilling inclinations. The best way to assess whether one's underlying disposition is good or evil is to identify which of these opposing attitudes one adopts toward the sufferings and ills experienced in this life.

Properly understanding the subtlety of Kant's suggestion that the punishment for past evil occurs during the change of heart enables us to clarify what he thinks a noumenal act is. The solution to the third difficulty implies that, in one sense, the required punishment takes place all in a flash, at the (timeless) moment when a person's disposition changes from evil to good. This solution to the problem of justification, Kant says, is "suprasensibly based" (i.e., noumenal). Yet, such a change makes practical sense (i.e., avoids encouraging the moral laziness at the root of all three ethical difficulties) only if we appeal (with Kant) to the religious symbolism of an archetype who has already completed this work. ${ }^{38}$ This archetype, viewed from the phenomenal perspective, is a person who continually strives to realize in actions the goodness already perfected in the disposition. To explain how a person, following the archetype, can experience a "continual becoming"

\footnotetext{
${ }^{38}$ Christians would identify Jesus as the best (and perhaps the only authentic) example. However, interpreting Kant's account of Jesus lies well beyond the scope of this article; see Stephen R. Palmquist “Could Kant's Jesus Be God?" an unpublished paper presented at the Philosophy of Religion Conference held at Hong Kong Baptist University, February 2009.
} 


\section{Kant's Ethics of Grace}

in (empirical) moral decision making, we must assume a "one-off decision" has been made from the noumenal perspective, a religious conversion whereby the person adopts a new way of interpreting the pain and suffering of living an earthly life; while this change is likely to increase one's suffering (viewed phenomenally), the converted person gradually learns (through faith in the efficacy of God's noumenal perspective) to interpret such experiences not as painful but with contentment and joy.

Kant sometimes seems to affirm the traditional Christian belief that Jesus plays a unique role in the human race's ability to achieve such a moral revolution (e.g., Religion 80, 158-62) and that each person's salvation somehow (at least in a symbolic sense) depends on Jesus's accomplishment (60-62, 119); yet he also affirms the Enlightenment philosophical belief that each person still has a duty to make the good principle the sovereign force in his or her will. The divine gift of the archetype may be free, but believers must do something to appropriate the righteousness it offers as their own. Kant's portrayal of grace as a noumenal idea in subsection $\mathrm{C}$ need not be dismissed as a muddle of lazy thinking; nor is it merely a "wild card" appeal to wishful thinking, comparable to the proverbial pink elephant. Instead, it functions as an ethical safety measure intended to supplement any Christian (or other) theology of grace: by forcing them to admit ignorance of how grace operates, Kant's position prevents believers from falling victim to an unethical application of theological doctrine, thereby providing them with the moral empowerment needed to persevere on the path of goodness. Viewing grace as a noumenal idea empowers believers by reminding them to ground the belief that they have received grace on the phenomenal evidence of their changed life conduct. In this way, Kant can both uphold salvation by grace alone (noumenally) and insist that believers must nevertheless endeavor to lead good lives (phenomenally).

Kant's solution to the three difficulties inherent in any belief in grace is considerably richer, and more amenable to a theology that offers believers access to a real, life-transforming power, than past interpreters have recognized. While Byrne's recent efforts to examine and assess Kant's appeal to divine assistance are a refreshing alternative to the more negatively inclined interpretations of the past, they do not go far enough along the path forged by scholars such as Quinn and Mariña. The interpretive key to resolving the conundrums of Kant's account is to recognize that he neither reduces grace to an optional extra, nor (even worse) dismisses it as nothing but the ravings of enthusiastic religious fanatics; rather, he rescues it from a far more per- 
The Journal of Religion

ilous fate, whereby belief in divine assistance encourages moral laziness, thus becoming a self-deceptive tool of radical evil that keeps one mired in an unethical way of life. Kant's appeal to the noumenal guards against such laziness, by requiring that we human beings must view our lives from the "progress" perspective, yet permitting us to hope God views our lives from the perspective of "the whole." The conduct we interpret as phenomenal progress does not "save" a person; it only provides the evidence that a noumenal change, an inner "revolution" (Religion, 47-48) has taken place; the divine wisdom has arranged the human situation so that we cannot know this noumenal reality, for this necessary ignorance is precisely what prevents us from being morally lazy. Kant is a philosopher, not a theologian, so he never claims to explain how grace happens; but neither does he deny the possibility of Christian (or other forms of) salvation. Rather, he brings together the warring parties he sees as his readers (theologians or religious believers who disdain philosophy on the one hand and irreligious philosophers or atheists on the other) by explaining how a person can believe in divine grace, even salvation by faith in the atoning sacrifice of Jesus, without becoming unethical.

Quinn raises two objections to Kant's theory that Mariña addresses, but only partially resolves. First, "Kantian justification is not merely mysterious; it is, on Kantian principles, utterly unjustified." ${ }^{39}$ But if Kant's aim is not to theologize about grace, this objection is misplaced; Kant merely needs to show how someone who chooses to believe in grace (whatever their reasons may be!) can avoid moral laziness. Ultimately for Kant, the question of human salvation can be answered by God alone. Second, Quinn claims that on Kantian principles, if God declares that a person who still sometimes sins is nevertheless righteous, this implies a "laxness" in divine justice that "would be a moral outrage." ${ }^{\prime 0}$ However, this objection neglects the perspectival grounding of Kant's argument. Such an objection only holds in the case of human judges, who must depend on phenomenal evidence alone. ${ }^{41}$ Kant's God does not base the decree of righteousness on phenomenal evidence; only we do that! God's decree of righteousness must be based on a noumenal disposition that (for a converted person) fully complies with the moral law and therefore involves no injustice on God's part.

Similarly, Adams objects: "Kant really has no explanation of how moral progress could deserve to be counted as perfected holiness." ${ }^{42}$

${ }^{39}$ Quinn, "Christian Atonement and Kantian Justification," 457.

${ }^{40}$ Ibid., 458.

${ }^{41}$ The common practice of law courts, discussed in $\mathrm{n} .37$ above, is a case in point.

${ }^{42}$ Adams, "Introduction," xxiv. 


\section{Kant's Ethics of Grace}

Thus he poignantly asks, "What's the point of imputed righteousness for a Kantian?" The point, I have argued, is that belief in such (prevenient!) grace empowers a good-hearted person to continue the struggle toward phenomenal perfection. Adams misleadingly thinks Kant's appeal to progress requires a mixture of good and evil influences on the noumenal level that Kant, with his previously defended "rigorist" stance, requiring a person's disposition always to be "either morally good or morally evil" and never both (Religion, 22), would firmly reject. Adams thinks the claim that the postconversion noumenal self is entirely good, from God's perspective, amounts to "denying the reality of sin and classifying it as merely an appearance." ${ }^{33}$ Yet this is no more true for Kant than it is for traditional Christian doctrine. Like the latter, Kant's position is that sin (radical evil) affects us on two levels: before conversion, it has a noumenal grip on our disposition and thus total control over our phenomenal choices; but after conversion, God (accurately) views the perfected disposition as sinless, even though we continue to struggle in our phenomenal choices as we progress toward the good. Adams is correct to say Kant places his hope in phenomenal "progress" as "the temporal expression of the timeless reality"; ${ }^{44}$ his mistake is to think this implies that a continuing struggle exists at the noumenal level as well.

Properly understood, belief in grace is not to be dismissed as an aberration or a sign of undue weakness, but affirmed as the goal of Kant's whole argument in Religion, and at least consistent with (if not also grounded by) his Critical System. ${ }^{45}$ That goal is aptly expressed by Kant himself, in the final sentence of Religion. Any doubt that Kant saw himself as defending an ethics of grace should be dispelled when we read his concluding claim to have confirmed the philosophical soundness of Jesus's central message in the Gospels (202), namely, "that the right way to advance is not from grace to virtue, but rather from virtue to grace."

\footnotetext{
${ }^{43}$ Ibid., xix.

${ }^{44}$ Ibid., xix-xx.

${ }^{45}$ For a defense of the latter claim, not argued here, see Palmquist, Kant's Critical Religion, esp. chaps. 7 and 12 .
} 